\title{
MINORITY HISTORIES, SUBALTERN PASTS
}

'...perhaps Abraham simply didn't do what the story says, perhaps in the context of his times what he did was something quite different. Then let's forget him, for why bother remembering a past that cannot be made into a present?' Soren Kierkegaard, Fear and Trembling (I843).

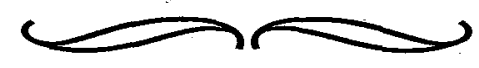

$\mathrm{R}_{\mathrm{e}}$ the Western democracies have often fuelled discussions of minority histories. As the writing of history has increasingly become entangled with the so-called 'politics and production of identity' after the Second World War, the question has arisen in all democracies of including in the history of the nation the histories of groups previously left out from it. In the r 960 s, this list usually contained names of subaltern social groups and classesviz., formers slaves, working-classes, convicts, women, etc. This came to be known in the seventies as 'history from below.' Under pressure from the debates on multiculturalism, this list was expanded in the seventies and eighties to include the so-called ethnic groups, the indigenous peoples, children, the old and gays and lesbians. The expression 'minority histories' would thus now refer to all those pasts on whose behalf democratically-minded historians have fought the exclusions and omissions of mainstream narratives of the nation. The last ten years, as a result, have seen the flourishing of almost a cult of pluralism in matters pertaining to history or memory. Official or officially-blessed accounts of the nation's past have been challenged in many countries by the champions of minority-histories. Postmodern critiques of 'grand narratives' have been used as ammunition in the process to argue that the nation cannot have just one standardized narrative, that the nation is always a contingent result of many contesting narratives. Minority histories, one may say, express the struggle for inclusion and representation that are characteristic of liberal and representative democracies.

Conceived in this way, 'minority histories' are oppositional chiefly in the early part of their careers. They are oppositional in so far as they are excluded from mainstream historical narratives; as soon as they are 'in', the oppositional stance becomes redundant (or its continuation would be seen as a sign of ingratitude if not something in bad taste). Begun in an oppositional mode, 'minority histories' end up being additional instances of 'good history.' They expand our vista and make the subject-matter of history more representative of society as a whole. One 
can ask legitimate Foucauldian questions about who has the authority to define what 'good' history is or what relationships between power and knowledge are invested in such definitions, but let us put them aside for the moment.

The transformation of oppositional, minority histories into 'good' histories illustrates how the mechanism of incorporation works in the discipline of history. History is a subject primarily concerned with the crafting of narratives. Any account of the past can be absorbed into, and thus made to enrich, the mainstream of historical discourse if two questions could be answered in the positive: Can the story be told/crafted? And does it allow for a rationally-defensible point of view or position from which to tell the story? The point about the authorial position being rationally defensible is important. It can be an ideology, a moral position, a political philosophy but, as we shall see, the choices here are not unlimited. A mad man's narrative is not history. Nor can a preference that is arbitrary or just personal--something based on taste, say-give us rationallydefensible principles for narration (at best it will count as fiction and not history). I will return to the issue of rationality. The other question of crafting, however, is what has enriched the discipline for a long time by challenging historians to be imaginative and creative both in their research and narrative strategies. How do you write the histories of suppressed groups? How do you construct a narrative of a group or class that has not left its own sources? It is questions of this kind that often stimulate innovation in historians' practices, and these questions, taken together, constitute what I call 'the question of crafting.

I give two instances to show, therefore, that so long as these two questions-can the story be told? And does it allow for a rationally-defensible position in public life from which to tell the story? - can be answered in the positive, the discipline has no serious problems incorporating into itself, or even making central to itself, what once occupied a marginal or minority position. 'Minority histories', as such, do not have to be subversive in the long run.

My first case is that of British socialdemocratic.history or so-called 'history from below.' Consider for a moment what the results have been of incorporating into the discourse of history the pasts of majority-minor groups such as the working classes and women. History has not been the same ever since a Thompson or a Hobsbawm took up his pen to make the working classes look like major actors in society, or since the time feminist historians made us realize the importance of gender-relations and of the contributions of women to critical social processes. So to the question as to whether or not such incorporation changes the nature of historical discourse itself, the answer is simple: of course, it does. But the answer to the 
question, Did such incorporation call the discipline into any kind of crisis? would have to be, No. To be able to tell the story of group hitherto overlooked, to be able to master the problems of crafting such narratives - particularly under circumstances where the usual archives do not exist-is how the discipline of history renews and maintains itself. For this inclusion appeals to the sense of democracy that impels the discipline ever outward from its core. Both conditions of history-writing were met in the tradition of 'history from below': the stories could be told provided one were creative and enterprising in one's research, and they could be told from a position (liberalism or Marxism) rationally-defensible in public life.

The point about historical narratives requiring a certain minimum investment in rationality has recently been made in the discussion of postmodernism in the book Telling the Truth About History. ${ }^{1}$ The question of the relationship between minority histories and post-war democracies is at the heart of this book authored jointly by three leading feminist historians of the U.S. To the extent that the authors read postmodernism as allowing for multiple narratives-the possibility of many narratives and multiple ways of crafting these narratives - they welcome the influence of postmodernism and thus align themselves with the democratic cause of minority histories. The idea of multiple narratives challenging any one dominant meta-narrative of the nation is easily accepted in the book which promotes the message popular now with most historians with a liberal conscience: Let us have many narratives and hear groups whose histories have not been previously heard, let there not be only the story of Eurocentric America as the grand narrative of the nation. Where the book registers a much stronger degree of discomfiture, however, is where it encounters arguments that in effect use the idea of multiplicity of narratives to question any idea of truth or facts. For here the idea of a rationally-defensible position in public life from which to craft even a multivocal narrative, is brought into question. If 'minority histories' go to the extent of questioning the very idea of fact or evidence, then, the authors ask, how would you find ways of adjudicating between competing claims in public life? Would not the absence of a certain minimum agreement about what constitutes fact and evidence seriously fragment the body politic in the United States of America and would not that seriously impair the capacity of the nation to function as a whole? Hence the authors recommend that a pragmatic idea of 'workable truths'--based on a shared, rational understanding of historical facts and evidence-must be maintained in order for institutions and groups to be able to adjudicate between conflicting stories/interpretations and for the nation to function effectively even while eschewing any claims to a superior, over- 
arching grand narrative. ${ }^{2}$ What Appleby and her colleagues see as postmodern resistance to the idea of facticity does not thus meet the second condition for incorporation into the discipline of history of other narratives about the past: Can the story be told on the basis of a rationally-defensible principle in public life? The book makes clear that citizenly practices require a certain minimụm agreement on such principles as otherwise the clamour of contesting narrative--based on completely arbitrary ideas of historical evidence--would reduce public life in American democracy to a chaos.

\section{I am not criticizing Telling the Truth} About History nor is it my purpose to defend what the book identifies as postmodern positions. The book is important in that it shows the continuing relevance of the two questions about crafting and connections to public life in any situation where the discipline of history hears calls to renew itself. I am simply saying that so long as the two conditions can be met 'minority histories' can change the discourse of the discipline without having to practice any principle of permanent revolution. Successful instances of 'minority histories' are like yesterday's revolutionaries become today's gentlemen. Their success helps routinize innovation.

The debate about minority histories, however, allows for another understanding of the expression 'minority', one that produces a more enduring sense of discomfort among many professional historians. Minority and majority are, after all, no natural entities; they are constructions, as I said at the outset, of identities made in very particular historical conditions and circumstances. The popular meaning of the words 'majority' and 'minority' are statistical. But the semantic fields of the words contain another idea: of being a 'minor' or a 'major' figure in a given context. For example, the Europeans, numerically speaking, are a minority in the total pool of humanity today and have been so for a while, yet their colonialism in the nineteenth century was based on certain ideas about being 'major' and 'minor': the idea, for example, that it was their histories which contained the majority instances of norms that every other human society should aspire to, or that compared to them others were the still the 'minors' for whom they, the 'adults' of the world, had to take charge. So numerical advantage by itself is no guarantor of a major/majority status. Sometimes, you can be a larger group than the dominant one, but your history could still qualify as 'minor/minority history.' The problem of 'minority histories' thus leads us, one could say, to the question of what may be called the 'minority' of some particular pasts, i.e. constructions and experiences of the past that stay 'minor' in the sense that their very incorporation into historical narratives converts them into pasts 'of lesser importance' vis-a-vis dominant understandings of what constitutes fact 
and evidence (and hence the underlying principle of rationality itself) in the practices of professional history. Such 'minor' pasts, one might say, are those experi-

ences of the past which have to be always made inferior as they are translated back into the historian's language, that is to say, as they are translated back into the phenomenal world the historian-as a historian, that is, in his or her professional capacity-inhabits. These are pasts that, to use Kant's expression from his essay 'What is Enlightenment?', are treated as instances of 'immaturity' on the part of the historical agent, pasts which do not prepare us for either democracy or citizenly practices because they are not based on the deployment of reason in public life. ${ }^{3}$

Let me call these histories subordinated or 'subaltern' pasts. They are not marginalized because anyone consciously intends to marginalise them but because they represent moments or points at which the very archive that the historian of a (marginalized) group mines in order to bring the history of that group into a relationship with a larger narrative (of class, of the nation, etc.), develops a degree of intractability with respect to the historian's project. In other words, these are pasts that resist historicization just as there may be moments in ethnographic research that resist the doing of ethnography.

'Subaltern pasts', in my sense of the term, do not belong exclusively to sociallysubordinate or subaltern groups, nor to 'minority' identities alone. Elite and dominant groups can also have subaltern pasts. Being a historian, however, I argue from a particular instance of it. My example comes from Subaltern Studies, the group with which I am associated, and from an essay by the founder of the group, Ranajit Guha. Since Guha and the group have been my teachers in many ways, I offer my remarks not in a hostile spirit of criticism but in a spirit of selfunderstanding, for my aim is to understand what 'historicizing' the past does and does not do. With that caveat, let me proceed to the instance.

Subaltern Studies is a series of publications in Indian history that was begun under the general editorship of Ranajit Guha in the early 1980 s. Its explicit aim was to write the subaltern classes into the history of nationalism and the nation and to combat all elitist biases in the writing of history. To make the subaltern the sovereign subject of history, to stage them as the agents in the process of history, to listen to their voices, to take their experiences and thought (and not just their material circumstances) seriously-these were goals we had deliberately and publicly set ourselves. These ambitions and the desire to enact them are political, they are connected to modern understandings of democratic public life; they do not necessarily come from the lives of the subaltern classes themselves. That is why the early intellectual moves made in Subaltern Studies had much in common with the British social- 
democratic tradition of writing 'history from below.' Looking back, however, I see the problem of 'subaltern pasts' dogging the enterprise of Subaltern Studies from the very outset and, indeed it is arguable that what differentiates the Subaltern Studies project from the older tradition of 'history from below' is the self-critical awareness of this problem in the writings of the historians associated with this group.

Let me explain this with the help of Ranajit Guha's justly celebrated and brilliant essay, 'The Prose of CounterInsurgency,' published in an early volume of Subaltern Studies and now considered a classic of the genre. A certain paradox that results precisely from the historian's attempt to bring the histories of the subaltern classes into the mainstream of the discourse of history in India, it seems to me, haunts the very exercise Guha undertakes in this essay. The paradox consists in this. A principal aim of Guha's essay is to use the Santal rebellion of ${ }_{1} 8_{55}$ in order to make the insurgent peasant's consciousness the mainstay of a narrative about rebellion. As Guha put it in words that capture the spirit of Subaltern Studies:

Yet this consciousness [the consciousness of the rebellious peasant] seems to have recerved little notice in the literature on the subject. Historiography has been content to deal with the peasant rebel merely as an empirical person or a member of a class, but not as an entity whose will and reason constituted the praxis called rebellion... insurgency is regarded as external to the peasant's consciousness and Cause is made to stand in as a phantom surrogate for Reason, the logic of that consciousness. ${ }^{4}$

The critical phrase is the logic of that consciousness' which marks the distance Guha has to take as a historian from the object of his research which is this consciousness itself. For in pursuing the history of the Santal rebellion of 1855 the Santals are a 'tribal' group inhabiting large areas of what is today Bengal and Bihar-Guha, unsurprisingly, comes across statements by peasant-leaders which explain the rebellion in 'supernatural' terms, as an act carried out at the behest of the Santal god 'Thakur.' Guha himself draws our attention to the evidence and underscores how important this understanding was to the rebels themselves. Quoting statements made by the leaders of the rebellion, Sidhu and Kanu, to military interrogators wherein they explained their own actions as flowing from instructions they had received from their god (Thakur) who had also assured them that British bullets would not harm the devotee-rebels, Guha takes care to avoid any instrumental or elitist reading of these statements. He writes:

These were not public pronouncements meant to impress their followers... these were words of captives facing execution. Addressed to hostile interrogators in military encampments they could have little use as propaganda. Uttered by men of a tribe which, according to all accounts had not yet learnt to lie, these represented the truth and nothing but the truth for their speakers. ${ }^{5}$ 
A tension inherent in the project of Subaltern Studies becomes palpable here in Guha's analysis. His phrase 'logic of consciousness' or his idea of a truth which is only 'truth for their speakers' are all acts of taking critical distance from that which he is trying to understand. Taken literally, the rebel peasants' statement show the subaltern himself as declining agency or subjecthood in action. 'I rebelled', he says, 'because Thakur made an appearance and told me to rebel.' In their own words, as reported by the colonial scribe: 'Kanoo and Sedoo Manjee are not fighting. The Thacoor himself will fight.' In his own telling, then, the subaltern is not necessarily the subject of his history but in the history of Subaltern Studies or in any democratically-minded history, s/he is. What does it then mean when we both take the subaltern's views seriously-the subaltern ascribes the agency for their rebellion to some god-and want to confer on the subaltern agency or subjecthood in their own history, a status the subaltern's statement denies?

Guha's strategy for negotiating this dilemma unfolds in the following manner. His first move, against liberal or standard Marxist historiography, is to resist analyses that see religion simply as the non-rational expression of a secular-rational non-religious entity, relationship (class, power, economy, etc.) or consciousness:

Religiosity was, by all accounts, central to the hool (rebellion). The notion of power which inspired it ...[was] explicitly religious in character. It was not that power was a content wrapped up in a form external to it called religion. ..Hence the attribution of the rising to a divine command rather than to any particular grievance; the enactment of rituals both before (eg. propitiatory ceremonies to ward off the apocalypse of the Primeval Serpents...) and during the uprising (worshipping the goddess Durga,

bathing in the Ganges, etc.); the generation and circulation of myth is its characteristic vehicle-rumour. ${ }^{6}$

But in spite of his desire to listen to the rebel voice seriously, Guha cannot take it seriously enough, for there is no principle in an 'event' involving the divine or the supernatural that can give us a narrative-strategy that is rationally-defensible in the modern understanding of what constitutes public life. The Santal's own understanding does not directly serve the cause of democracy or citizenship or socialism. It needs to be reinterpreted. Clearly, in the narrative of the rebels, the Event (the rebellion) was not secular; in our language, it included the supernatural. The supernatural was part of what constituted public life for the nonmodern Santals of the nineteenth century. This, however, simply cannot be the past in the language of professional history in which the idea of historical evidence, like evidence allowed in the court of law, cannot admit of the supernatural except as part of the non-rational (i.e. somebody's belief-system).

Fundamentally, the Santal's statement that God was the main instigator of the 
rebellion has to be anthropologized (i.e. converted into somebody's belief) before it finds a place in the historian's narrative. Guha's position with respect to the Santal's own understanding of the event becomes a combination of the anthropologist's politeness - I respect your beliefs but they are not mine'--and a Marxist (or modern) sense of frustration with the intrusion of the supernatural into public life. '[I]n sum', he writes, 'it is not possible to speak of insurgency in this case except as a religious consciousness', and yet hastens to add:

-except that is, as a massive demonstration of self-estrangement (to borrow Marx's term for the very essence of religiosity) which made the rebel look upon their project as predicated on a will other than their own. ${ }^{7}$

Here is a case of what I have called 'subaltern pasts', pasts that cannot enter history ever as belonging to the historian's own position. One can these days devise strategies of multivocal histories in which we hear Sidhu and Kanu more clearly than we or Guha did in the early phase of Subaltern Studies. One may even refrain from assimilating these different voices to any one voice and deliberately leave loose ends in one's narrative (as does Shahid Amin in his Events, Memory, Metaphor). ${ }^{8}$ But the point is the historian, as historian, and unlike the Santal, cannot invoke the supernatural in explaining/describing an event.

In other words, the act of championing 'minority histories' has resulted in many cases in discoveries of subaltern pasts, constructions of historicity that help us see the limits to the mode of viewing embodied in the practices of the discipline of history. Why? Because, it has been argued by many (from Greg Dening to David Cohen in recent times), that the discipline of history is only one particular way of remembering the past. It is one amongst many. ${ }^{9}$ The resistance that the 'historical evidence' offers in Guha's essay to the historian's reading of the past-a Santal god, Thakur, stands between the democratic-Marxist historian and the Santals in the matter of deciding who is the subject of history-is what produces 'minor' or 'subaltern' pasts in the very process of the weaving of modern historical narratives. Subaltern pasts are like stubborn knots that break up the otherwise evenly woven surface of the fabric. Between the insistence of the Subaltern Studies historian that the Santal is the agent or the subject of his own action and the Santal's insistence that it was to their god Thakur that such sovereignty belonged, remains a hiatus separating two radically different experiences of historicity, a hiatus that cannot be bridged by an exercise that simply studies the Santal's statement as evidence for anthropology. When we do 'minority histories' within the democratic project of including all groups and peoples within mainstream history, we both hear and then anthropologize the Santal. We treat their beliefs as just that, 'their beliefs.' We cannot write history from 
within those beliefs. We thus produce 'good', not subversive, histories.

However, historians of Pacific islands, of African peoples, of indigenous peoples throughout the world have reminded us that the so-called societies 'without histories'-the object of contempt for European philosophers of history in the nineteenth century-cannot be thought of as societies without memories. They remember their pasts differently, differently, that is, to the way we recall the past in the history departments. Why must one privilege the ways in which the discipline of history authorizes its knowledge? This is not a rhetorical question. It is a question being asked seriously by many historians today. ${ }^{10}$

This fact has an important implication: it suggests that the kind of disciplinary consensus around the historian's methods that was once-say, in the sixties-represented (in Anglo-American universities at least) by 'theory' or 'methods' courses which dished out

Collingwood or Carr or Bloch as staple for historians working on any area of the world, has now broken down. This does not necessarily mean methodological anarchy (though some feel insecure enough to fear this) or that Collingwood et al have become irrelevant but it does mean that E H Carr's question 'What is History?' needs to be asked again for our own times. The pressure of plurality inherent in the languages and moves of minority histories-which, as I have argued, is really the pressure that debates about multi-culturalism puts on official or nationalist histories in the Western democracies--has resulted in methodological and epistemological questioning of what the very business of writing history is all about. Only the future will tell how these questions will resolve themselves but one thing is clear: that the question of including 'minorities' in the history of the nation has turned out to be a much more complex problem than a simple operation of applying some already-settled methods to a new set of archives and adding the results to the existing collective wisdom of historiography. The additive, 'building-block' view of knowledge has broken down. What has become an open question is: Can the discipline of history speak for any kind of experience of the past? Are there experiences of the pasts that cannot be captured by the methods of the discipline or which at least show the limits of discipline?

Fears that such questioning will lead to a breakout of irrationalism, that some kind of postmodern madness will spread like a dark death-inducing disease through Historyland, seem extreme, for the discipline is still securely tied to the positivist impulses of modern bureaucracies, judiciary and to the instruments of governmentality. Minority histories, if they are going to be about inserting hitherto neglected identities into the game of social justice, must also be good, and not subversive, histories, for history here speaks to forms of representative democracy 
and social justice that liberalism or Marxism have already made familiar.

Attending to the limits of history is about another realization: that the task of producing 'minority' histories has, under the pressure precisely of a deepening demand for democracy, become a double task. I may put it thus: 'good' minority history is about expanding the scope of social justice and representative democracy, but the talk about the limits of history', on the other hand, is about fighting for forms of democracy that we cannot not yet either completely understand or envisage. This is so because in the mode of being attentive to the 'minor-ity' of subaltern pasts, we stay with heterogeneity without seeking to reduce it to any overarching principle that speaks for an already-given whole. There is no third voice which can assimilate into itself the two different voices of Guha and the Santal leader, we have to stay with both, with the gap between them that signals an irreducible plurality in our own experiences of historicity.

This is the way I understand the question of heterogeneity here. We can-and we do usually in writing history-- treat the Santal of the nineteenth century to doses of historicism and anthropology. We can, in other words, treat him as a signifier of other times and societies. This gesture maintains a subject-object relationship between the historian and his evidence. In this gesture, the past remains genuinely dead; the historian brings it 'alive' by his or her telling of the story.
But the Santal with his statement 'I did as my god told me to do' also faces us a way of being in this world, and we could ask ourselves: Is that way of being a possibility for our lives and for what we define our present? Does the Santal help us to understand a principle by which we also live in certain instances? This question does not historicize or anthropologize the Santal, for the illustrative power of the Santal as an example of a present possibility does not depend on the particular period or society from which the example is drawn. In this mode of understanding the Santal stands as our contemporary and the subject-object relationship that normally defines the historian's relationship to his/her archives is dissolved in this gesture. This gesture is akin to the one Kierkegaard developed in critiquing explanations that looked on the Biblical story of Abraham's sacrifice of his son Isaac either through psychology or as a metaphor or allegory but never as a possibility for action open to him/her who had faith. '[W]hy bother to remember a past,' asked Kierkegaard, 'that cannot be made into a present?'11 To stay with the heterogeneity of the moment when Guha the historian meets with the Santal, the peasant, is then to stay with the difference between these two gestures: that of historicizing the Santal in the interest of a history of social justice and democracy, the other of refusing to historicize and of seeing the Santal instead as throwing light on a possibility for the present. When seen as the latter, 
the Santal puts us in touch with the heterogeneities, the plural ways of being, that make up our own present. The archives thus help bring to view the disjointed nature of our own times. That is the function of subaltern pasts: a necessary penumbra of shadow to the area of the past that the method of history successfully illuminates, they make visible what historicizing does and what it cannot do.

Attending to this heterogeneity could take many different forms. Some scholars now perform the limits of history by fictionalizing the past, by experimenting to see how films and history might intersect in the new discipline of cultural studies, by studying memory rather than just history, by playing around with forms of writing, and by similar other means. While such experiments are welcome, let me conclude with a point about how the fact that there are subaltern pasts, unassimilable to the secular narratives of the historian, allows us to see the complex understanding of timetreated as invisible in most historian's writing-- that must underlie and indeed make possible the secular chronology of historical narratives, the construction of before-after relationships without which there cannot be any historical explanation. Let me elucidate.

The broad statement that the Santal had a past in which events could belong to the order of the supernatural does not appear as something completely beyond our own experience-it is not something like a possible statement from a Martian.

Why? Because the principle is not completely strange to us. We have a pre-theoretical, everyday understanding of it precisely because the supernatural or the divine, as principles, have not disappeared from the life of the modern. We are not the same as the nineteenthcentury Santal. One could even easily assume that the Santal today would be very different from what they were in the nineteenth century, that they would inhabit a very different set of social circumstances. The modern Santal would have the benefit of secular education and may even produce their own professional historians. No one would deny these historical changes. But the astrological columns in the newspapers (in spite of Adorno's frustrations with them), the practices of 'superstition' that surround the lives and activities of sportsfans, for example, practices we are too embarrassed to admit in public - not to speak of all the deliberately 'cultic' expressions of religiosity that have never gone awaygo to show that we are all, in principle, capable of participating in supernatural events and the sense of the past they help create. The nineteenth-century Santaland indeed, if my argument is right, humans from any other period and regions--are thus in a peculiar way our contemporaries: that, I would argue, would have to be the condition under which they become intelligible to us. Thus the writing of history must implicitly assume a plurality of times existing together, a 
discontinuity of the present with itself. Making visible this discontinuity is what 'subaltern pasts' allow us to do.

An argument such as this is actually at the heart of modern historiography itself. One could argue, for instance, that the writing of 'medieval history' for Europe depends on this assumed contemporaneity of the medieval, or what is the same thing, the non-contemporaneity of the present with itself. The medieval in Europe is often strongly associated with the supernatural and the magical. But what makes the historicizing of it at all possible is the fact that its basic characteristics are not completely foreign to us as moderns (which is not to deny the historical changes that separate the two). Historians of medieval Europe do not always consciously or explicitly make this point but it is not difficult to see this operating as an assumption in their method (in the same way as anthropologists may refer to examples more familiar to their readers in order to explain that which seems strange at first). In the writings of Aron Gurevich, for example, the modern makes its pact with the medieval through the use of anthropology-that is, in the use of contemporary anthropological evidence from outside of Europe to make sense of the past of Europe. The strict separation of the medieval from the modern is here belied by their contemporaneity suggested by anthropology: Peter Burke comments on this intellectual traffic between medieval Europe and contem- porary anthropological evidence in introducing Gurevich's work. Gurevich, writes Burke, 'could already have been described in the ig6os as a historical anthropologist, and he did indeed draw inspiration from anthropology, most obviously from the economic anthropology of Bronislaw Malinowski and Marcel Mauss, who had begun his famous essay on the gift with a quotation from a medieval Scandinavian poem, the $E d d a$. $^{12}$

Similar double moves--both of historicizing the medieval and of seeing it at the same time as contemporary with the present-can be seen at work in the following lines from Jacques Le Goff. Le Goff is seeking to explain here an aspect of the European-medieval:

$$
\begin{aligned}
& \text { People today, even those who consult seers } \\
& \text { and fortune-tellers, call spirits to floating } \\
& \text { tables, or participate in black masses, recog- } \\
& \text { nize a frontier between the visible and the } \\
& \text { invisible, the natural and the supernatural. } \\
& \text { This was not true of medieval man. Not only } \\
& \text { was the visible for him merely the trace of } \\
& \text { the invisible; the supernatural overflowed } \\
& \text { into daily life at every turn. }{ }^{3}
\end{aligned}
$$

This is a complex passage. On the surface of it, it is about what is separates the medieval from the modern. Yet the difference is what makes the medieval an ever-present possibility that haunts the practices of the modern - if only we, the moderns, could forget the 'frontier' between the visible and the invisible in Le Goff's description, we would be on the other side of that frontier. The people 
who consult seers today are modern in spite of themselves, for they engage in 'medieval' practices but are not able to overcome the habits of the modern. Yet the opening expression 'even today' contains a reference to the sense of surprise one feels at their anachronism, as if we did not expect to find such practices today, as if the very existence of these practices today opens up a hiatus in the continuity of that present by inserting into it something that is medieval-like and yet not quite so. It makes the present look like as though it were non-contemporaneous with itself. Le Goff rescues the present by saying that even in the practice of these people, something irreducibly modern lingerstheir distinction between the visible and the invisible. But it lingers only as a border, as something that defines the difference between the medieval and the modern. And since difference is always the name of a relationship, for it separates just as much as it connects as indeed does a border, one could argue that alongside the present or the modern the medieval must linger as well if only as that which exists as the limit or the border to activities that define the modern.

Subaltern pasts are signposts of this border. With them we reach the limits of the discourse of history. The reason for this, as I have said, is that subaltern pasts do not give the historian any principle of narration that can be rationally-defended in modern public life. Going a step further, one can see that this requirement for a rational principle, in turn, marks the deep connections that exist between modern constructions of public life and projects of social justice. That is why a Marxist scholar like Fredric Jameson begins his book The Political Unconscious with the injunction: 'Always historicize!' 'This slogan,' writes Jameson, 'the one absolute and we may even say "transhistorical" imperative of all dialectical thought-will unsurprisingly turn out to be the moral of The Political Unconscious as well.' ${ }^{14}$ If my point is right, then historicizing is not the problematic part of the injunction, the troubling term is 'always'. For the assumption of a continuous, homogeneous, infinitely-stretched out time which makes possible the imagination of an 'always,' is put to question by subaltern pasts that makes the present, as Derrida says, 'out of joint', non-continuous with itself. ${ }^{15}$ One historicizes only in so far as one belongs to a mode of being in the world which is aligned with the principle of 'disenchantment of the universe' that underlies knowledge in the social sciences (and I distinguish knowledge from practices). It is not accidental that a Marxist would exhort us to 'always historicize', for historicizing is tied to the search for justice in public life. This is why one welcomes 'minority histories', be they of ethnic groups, gay-rights activists, or of subaltern social classes. Here the historical discipline enriches itself by incorporating these histories but 
its very methodological dominations create what I have called subaltern pasts.

For the 'disenchantment of the world' is not the only principle by which we world the earth. There are other modes of being in the world-and they are not necessarily private, the superstitious acts of sportsfans, for example, being often public. The supernatural can inhabit the world in these other modes and not always as a problem or result of belief; the supernatural or the divine can be brought into presence by our practices. Here I am reminded of the story of the old Irish woman who allegedly, once while asked by Yeats whether or not she believed in fairies, insisted that while she did not believe in them, her disbelief did not stop them from existing - "They are there Mr Yeats, they are there. ${ }^{16}$ These other worlds are not without questions of power or justice but these questions are raised - to the extent modern public institutions allow them--on terms other than those of the political-modern.

However,- - and I want to conclude by pointing this out - the relation between what I have called 'subaltern pasts' and the practice of historicizing (that the Marxist in us recommends) is not one of mutual exclusion. It is because we always already have experience of that which makes the present non-contemporaneous with itself that we can actually historicize. Thus what allows medievalist historians to historicize the medieval or the ancient is the very fact these worlds are never completely lost. It is because we live in time-knots that we can undertake the exercise of straightening out some part of the knot (which is what a chronology is). ${ }^{17}$ Subaltern pastsaspects of these time-knots - thus act as a supplement to the historian's pasts and in fact aid our capacity to historicize. They are supplementary in a Derridean sense - they enable history, the discipline, to be what it is and at the same time help to show forth what its limits are. But in calling attention to the limits of historicizing, they help us distance ourselves from the imperious instincts of the discipline - the idea (of Haldane's for example) that everything can be historicized or that one should always historicize - and returns us to a sense of the limited good that the modern historical consciousness is. Gadamar once put the point well in the course of discussing Heidegger's philosophy. Let me give him the last word: "The experience of history, which we ourselves have, is ... covered only to a small degree by that which we would name historical consciousness. ${ }^{18}$ Subaltern pasts persistently remind us of the truth of this statement.

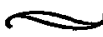

An earlier version of this essay was presented at the annual conference of the American Historical Association in January r997. I acknowledge with gratitude the criticisms and comments I received there. A subsequent presentation at the University of Colorado at Boulder at the invitation of my copanelist Patricia Limerick also benefited 
from the criticisms of those present. I thank Sandria Freitag for her original invitation prodding me to think this topic and Anne Hardgrove and Uday Mehta for more recent conversations on the subject. All errors remain mine.

\section{REFERENCES}

1 Joyce Appleby, Lynn Hunt, Margaret Jacob, Telling the Truth About History (New York, r994).

2 Cf. Georg G.Iggers, Historiography in the Twentieth Century: From Scientific Objectivity to the Postmodern Challenge, (Hanover and London, 1997), p. I45: 'Peter Novick has in my opinion rightly maintained that objectivity is unattainable in history; the historian can hope for nothing more than plausibility. But plausibility obviously rests not on the arbitrary invention of an historical account but involved rational strategies of determining what in fact is plausible.' Emphasis added.

3 Immanuel Kant, 'An Answer to the Question: What Is Enlightenment?' (1784) in Immanuel Kant, Perpetual Peace and Other Essays, trans. Ted Humphrey (Indianapolis, 1983 ), pp.41-48.

4 Ranajit Guha, "The Prose of CounterInsurgency' in Ranajit Guha and Grayatri Chakravorty Spivak eds., Selected Subaltern Studies (New York, rg88), pp.46-47.

5 Ibid., p.8o.
6 Ibid., p.78.

7 Ibid., p.78.

8 Shahid Amin's book Events, Memory,

Metaphor (Berkeley, I995) is an excellent illustration of the points being made in this essay and shows a self-conscious appreciation of the problems of translating the subaltern's voice into a modern political project (without giving up the sociallynecessary attempt to translate).

9 See Greg Dening's essay 'The Poetics of History' in his Performances (Chicago, 1995) and David Cohen's The Combing of History (Chicago, 1994). Ashis Nandy's essay 'Themes of State, History and Exile in South Asian Politics', Emergences, No.7/8, I995-96, pp Io4-I25 makes comparable points.

10 A sensitivity to the question of alternative pasts is increasingly becoming visible in the work of many historians: my very personal and random list of such scholars would include Klaus Neumann, Stephen Muecke, Christopher Healy, Patricia Limerick, Ajay Skaria, Saurabh Dube. Sumathi Ramaswamy, Iain McCalman and others.

11 See Soren Kierkegaard, Fear and Trembling: Dialectical Lyric by Johannes de silentio, trans. Alastair Hannay (Harmondsworth, 1985 ), p.6o. 
12 Peter Burke, 'Editorial Preface' to Aron Gurevich, Medieval Popular Culture: Problems of Belief and Perception, trans. Janos M Back and Paul A Hollingsworth (Cambridge, I990), p.vii.

13 Jacques Le Goff ed. The Medieval World, trans. Lydia G. Cochrane (London, 199o), pp.28-29.

14 Preface' to his The Political Unconscious: Narrative as a Socially Symbolic Act (New York, I98I), p.9.
15 See Jacques Derrida, Specters of Marx: The State of the Debt, the Work of Mourning, \& the New International, trans. Peggy Kamuf (New York and London, 1994).

16 I owe this story to David Lloyd.

17 I owe the conception of time-knots to Ranajit Guha.

18 Hans-Georg Gadamar, 'Kant and the Hermeneutical Turn' in his Heidegger's Ways trans. John W. Stanley (New York, 1994), p. 58 . Emphasis in the original.

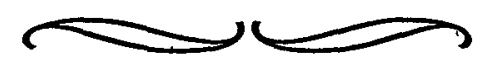

